\title{
PENGATURAN PENYERAHAN PROTOKOL NOTARIS YANG TELAH MENINGGAL DUNIA DAN PRAKTEKNYA DI PROVINSI SUMATERA BARAT*
}

\author{
Yofi Permana. R \\ Pascasarjana Strata II Fakultas Hukum, Universitas Andalas Padang \\ e-mail : yoppi.permana@yahoo.co.id
}

\begin{abstract}
Abstrak
The Notary Protocol is a collection of documents that is a state archive that must be stored and maintained by a Notary. Regarding the Notary protocol and its submission are regulated in article 63 UUJN and UUJN. If the Notary dies, the Notary protocol shall be submitted by the heir to the MPD or other Notary Public. The purpose of this writing is to analyze the provisions of the Law on the Submission of Notary Protocols who have died, their practices and the responsibilities of the heirs to the Notary Protocol and legal actions taken by the MPD for the Notary Protocol that have not been submitted. This research uses an empirical juridical approach method. Article 63 UUJN and UUJNP have been explained regarding the surrender of the notary protocol that has died, but in practice there is a discrepancy with the applicable regulations, this is due to the lack of education and socialization from the Notary himself to the heirs or his family. If the Notary Protocol is not immediately submitted to the Notary Recipient of the protocol, then the MPD as a Notary supervisory agency is authorized to take the notary protocol that has not been submitted and give it to the Notary recipient of the Notary protocol. In carrying out his position as the notary recipient of the protocol, of course there must be a legal basis in the form of a Decree from the Minister of Law and Human Rights regarding the appointment of a Notary Public receiving the Notary Protocol, but in practice there are still notaries who have not yet received the Decree, this is due to the inadequacy of the decision of the MPD by the Minister of Justice and HumanRights.
\end{abstract}

Keywords: Notary Protocol; Notary; Notary Heir; MPD.

\begin{abstract}
Abstrak
Protokol Notaris adalah kumpulan dokumen yang merupakan arsip negara yang harus disimpan dan dipelihara oleh Notaris. Mengenai protokol Notaris dan penyerahannya diatur dalam pasal 63 UUJN dan UUJN. Apabila Notaris meninggal dunia maka protokol Notaris diserahkan oleh ahli waris kepada MPD atau Notaris lain. Penulisan ini bertujuan untuk menganalisis ketentuan Undang-undang mengenai Penyerahan protokol Notaris yang telah meninggal duni, prakteknya serta tanggungjawab ahli waris terhadap protokol Notaris dan tindakan hukum yang dilakukan oleh MPD terhadap protokol Notaris yang belum diserahkan, Penelitian ini menggunakan Metode pendekatan secara yuridis empiris. Pada pasal 63 UUJN dan UUJNP telah dijelaskan mengenai penyerahan protokol Notaris yang telah meninggal dunia, akan tetapi dalam prakteknya di lapangan terjadi ketidak sesuaian dengan peraturan yang berlaku, hal ini disebabkan karena minimnya edukasi dan sosialisasi dari Notaris itu sendiri kepada ahli waris atau keluarganya. Apabila Protokol Notaris tersebut tidak segera diserahkan kepada Notaris Penerima protokol, maka MPD selaku lembaga pengawas Notaris berwenang untuk mengambil protokol Notaris yang belum diserahkan tersebut dan memberikan kepada Notaris penerima protokol Notaris. Dalam menjalankan jabatannya selaku Notaris penerima protokol tentunya harus ada dasar hukum berupa Surat Keputusan dari Menteri Hukum dan HAM tentang pengangkatan Notaris penerima Protokol Notaris, tetapi dalam prakteknya masih ada Notaris yang belum menerima Surat Keputusan tersebut, hal ini dikarenakan kurang terakomodirnya keputusan dari MPD oleh Menteri Hukum dan HAM.
\end{abstract}

Kata kunci : Protokol Notaris; Notaris; Ahli Waris Notaris; MPD.

\footnotetext{
* Naskah diterima: 12 Januari 2019, direvisi: 12 Agustus 2019, disetujui untuk terbit: 30 September 2019

Doi: $10.3376 /$ jch.v5i1.120
} 
Yofi Permana. R: Pengaturan Penyerahan Protokol Notaris Yang Telah Meninggal Dunia...

\section{PENDAHULUAN}

Notaris adalah Pejabat Umum yang diangkat oleh negara untuk melaksanakan sebagian dari tugas negara. Dalam Pasal 1 butir 1 Undang-undang Nomor 30 Tahun 2004 tentang Jabatan Notaris dan Undang-undang Nomor 2 Tahun 2014 tentang Perubahan atas Undang-undang Nomor 30 tahun 2004 tentang Jabatan Notaris dijelaskan mengenai pengertian Notaris dikaitkan dengan tugas jabatan yang dibebankan kepadanya. Dari penjelasan Pasal 1 butir 1 UU Nomor 30

Tahun 2004 jo. UU Nomor 2 Tahun 2014 tersebut mengatakan bahwa tugas pokok dari seorang Notaris ialah membuat akta-akta autentik. Adapun akta autentik menurut Pasal 1868 Kitab UndangUndang Hukum Perdata (untuk selanjutnya disebut KUH Perdata) adalah suatu akta yang di dalam bentuk yang ditentukan oleh undang-undang, dibuat oleh atau di hadapan pegawai-pegawai umum yang berkuasa untuk itu di tempat dimana akta itu dibuatnya. Hal ini memberi pengertian bahwa Notaris karena undang-undang diberi wewenang menciptakan alat pembuktian yang mutlak, dalam pengertian bahwa apa yang tersebut dalam akta autentik itu pada pokoknya dianggap benar.

Jabatan Notaris tidak selamanya dapat di jabat oleh seorang Notaris, hal ini dapat dilihat dengan adanya batasan umur bagi seorang Notari dalam menjalankan tugas-tugas profesi Notaris tersebut. Sama halnya dengan Pegawai Negeri Sipil, Notaris juga mengenal batas usia maksimum dalam menjalankan jabatannya sebagai Notaris seperti yang telah ditentukan oleh UUJN. Dalam Pasal 8 ayat (1) UU Nomor 30 Tahun 2004 disebutkan bahwa:

"Notaris berhenti atau diberhentikan dari jabatannya dengan hormat karena:

a Meninggal dunia;

b. Telah berumur 65 (enam puluh lima) tahun;

c. Permintaan sendiri;

d. Tidak mampu secara rohani dan/atau jasmani untuk melaksanakan tugas jabatan Notaris secara terus menerus lebih dari 3 (tiga) tahun;

e. Merangkap jabatan sebagaimana dimaksud dalam pasal 3 huruf g."

Dari Pasal diatas dijelaskan bahwa ada beberapa hal yang menjadi alasan seorang Notaris tidak lagi menjabat. Misalnya saja karena Notaris yang bersangkutan telah meninggal dunia dan atau telah berakhir masa jabatannya, dalam hal ini telah memasuki usia 65 (enam puluh lima) tahun.

Berhentinya jabatan seseorang sebagai Notaris salah satunya disebabkan karena Notaris yang bersangkutan telah meninggal dunia. Dengan meninggalnya seorang Notaris mengakibatkan segala tanggung jawabnya berakhir dan protokol-protokol Notaris yang bersangkutan harus segera diserahkan kepada Majelis Pengawas Daerah (untuk selanjutnya disebut MPD) melalui ahli warisnya untuk kemudian disimpan oleh Notaris pemegang protokol yang telah ditunjuk. Keterangan tersebut ditegaskan dalam Pasal 63 ayat (2) UU Nomor 30 
Tahun 2004 jo. UU Nomor 2 Tahun 2014 yaitu:

"Dalam hal terjadi sebagaimana dimaksud dalam Pasal 62 huruf a, penyerahan Protokol Notaris dilakukan oleh ahli waris Notaris kepada Notaris lain yang ditunjuk oleh Majelis Pengawas Daerah.”

Protokol Notaris merupakan arsip negara, sehingga wajib disimpan dan dipelihara oleh Notaris dengan penuh tanggung jawab. Pasal 1 butir 13 UU Nomor 30 Tahun 2004 dan UU Nomor 2 Tahun 2014 menyebutkan bahwa yang dimaksud dengan Protokol Notaris adalah kumpulan dokumen yang merupakan arsip negara yang harus disimpan dan dipelihara oleh Notaris sesuai dengan ketentuan peraturan perundang-undangan. Penyimpanan dan pemeliharaan Protokol Notaris tersebut terus berlangsung walaupun Notaris yang bersangkutan telah memasuki usia 65 (enam puluh lima) tahun atau telah meninggal dunia. Berakhirnya masa jabatan seseorang sebagai Notaris menyebabkan berakhir pula kedudukannya sebagai Notaris, sedangkan Notaris sebagai suatu jabatan, akan tetap ada dan akta-akta yang dibuat di hadapan atau oleh Notaris yang bersangkutan akan tetap diakui dan akan disimpan (sebagai suatu kesinambungan) oleh Notaris pemegang protokolnya. (Habieb Adjie, 2008: 40).

Penjelasan Pasal 65 UUJN menurut Habib Adjie bahwa: (Habieb Adjie, 2009: 5)

1. Setiap orang yang diangkat sebagai Notaris, Notaris pengganti, Notaris pengganti khusus, dan pejabat sementara Notaris dianggap sebagai menjalankan tugas pribadi dan seumur hidup sehingga tanpa batas waktu pertanggungjawaban.

2. Pertanggungjawaban Notaris, Notaris pengganti, Notaris pengganti khusus, dan pejabat sementara Notaris dianggap melekat, kemana pun dan dimana pun mantan Notaris, mantan Notaris pengganti, mantan Notaris pengganti khusus, dan mantan pejabat sementara Notaris berada.

Hal ini berbeda dengan pendapat dari Sjaifurrachman, bahwa di Indonesia tidak dikenal tanggung jawab secara mutlak tanpa batas waktu, sehingga dapat diartikan tidak ada jabatan di Indonesia yang tanggung jawabnya tanpa batas. Oleh karena itu setiap jabatan apapun mempunyai batasan waktu tanggung jawab sepanjang yang bersangkutan menjabat atau karena apabila jabatan yang dipangku seseorang telah habis, yang bersangkutan berhenti pula tanggung jawabannya dalam jabatan yang pernah dipangkunya. (Sjaifurrachman, 2011:192193) Jika dibandingkan antara kedua pendapat tersebut, terlihat bahwa adanya perbedaan yang mendasar. Menurut Habib Adjie tanggung jawab tidak akan berakhir karena tanggung jawab melekat pada diri pribadi seorang Notaris, sedangkan menurut Sjafurrachman tanggung jawab tidak ada yang tidak memiliki batas waktu. Apabila melihat tanggung jawab dari segi pembuatan akta, seorang Notaris akan selalu dilekati oleh tanggung jawab secara materil manakala 
Yofi Permana. R: Pengaturan Penyerahan Protokol Notaris Yang Telah Meninggal Dunia...

suatu saat (meskipun telah berakhir masa jabatannya) akta yang dibuat oleh seorang Notaris didapati bermasalah dan diperlukan adanya pertanggungjawaban dari Notaris yang bersangkutan.

Tanggung jawab seorang Notaris secara administrasi adalah menerima, menyimpan, serta memegang bentuk fisik dari setiap akta yang merupakan Protokol Notaris yang harus dijaga dan dipelihara supaya tidak terjadi kehilangan, protokol Notaris tersebut berakhir bersamaan dengan dengan berakhirnya masa jabatan seorang Notaris. Sehingga, tanggung jawab seorang Notaris terhadap penyimpanan akta dapat berakhir namun pertanggungjawaban atas adanya kesalahan dalam pembuatan akta tidak akan pernah berakhir meskipun Notaris yang bersangkutan telah berakhir masa jabatannya.

Notaris dalam menjalankan profesinya senantiasa diawasi oleh suatu majelis yang disebut Majelis Pengawas Notaris (Selanjutnya disebut MPN) selama menjalankan jabatannya. MPN menjalankan fungsi pengawasan terhadap segala kegiatan Notaris. Pengawasan dilakukan dengan membentuk 3 (tiga) lembaga pengawas, yakni Majelis Pengawas Pusat (MPP) yang berkedudukan di Pusat, Majelis Pengawas Wilayah (MPW) yang berkedudukan di wilayah Propinsi, serta Majelis Pengawas Daerah (MPD) yang berkedudukan di wilayah Kabupaten/Kota. Keberadaan majelis pengawas dibentuk oleh Menteri Hukum dan Hak Asasi Manusia sebagaimana diatur dalam Pasal 67 ayat
(1) UU Nomor 30 Tahun 2004 dan UU Nomor 2 Tahun 2014.

Majelis Pengawas Notaris yang dalam hal ini dilakukan oleh MPD berhak menunjuk Notaris lain dan/atau berdasarkan usulan dari Ahli Waris Notaris yang telah meninggal dunia tersebut yang diteruskan kepada Menteri sebagai Notaris pemegang protokol Notaris yang telah meninggal dunia.

Notaris penerima protokol mempunyai peranan yang sangat penting dalam kehidupan masyarakat, sesuai dengan Pasal 16 ayat (1) huruf b dan d undang-undang Jabatan Notaris atau yang lazim dikenal sebagai UUJN, mewajibkan setiap Notaris untuk menyimpan minuta akta sebagai bagian dari protokol Notaris dan mewajibkan setiap Notaris untuk mengeluarkan grose akta, salinan akta, atau kutipan akta berdasarkan pada minuta akta atas permintaan para pihak atau ahli waris dari para pihak. Dalam hal ini Notaris penerima protokol perlu berhati-hati dalam penyimpanan setiap protokol Notaris yang diserahkan terimakan kepadanya. Menurut Habib Adjie, (Habib Adjie, 2008:45)

"Penyimpanan protokol Notaris oleh Notaris pemegang protokol Notaris merupakan suatu upaya untuk menjaga umur yuridis akta Notaris sebagai alat bukti yang sempurna bagi para pihak atau ahli warisnya tentang segala hal yang termuat dalam akta tersebut. Akta Notaris dalam bentuk salinan selamanya akan ada jika di simpan oleh yang bersangkutan, dan dalam bentuk minuta juga akan ada selamanya, yaitu yang disimpan oleh 
Notaris sendiri atau oleh Notaris pemegang protokol atau majelis Pengawas Daerah. Meskipun Notaris meninggal dunia tetapi akta Notaris akan tetap ada dan mempunyai umur yuridis, melebihi umur biologis Notaris.',

Dewasa ini, dengan perkembangan zaman dan kemajuan teknologi tidak luput juga dengan ketentuan atau batasan umur dari seorang manusia, menyimpang dari ketentuan masa pensiun seorang Notaris yaitu dengan meninggalnya seseorang merupakan suatu hal yang tidak lepas dari kehidupan, karena penulis memiliki pandangan dengan adanya kehidupan pasti akan ada kematian, tetapi penulis sendiri tidak tahu kapan datangnya kematian tersebut.

Dalam hal Notaris meninggal dunia maka protokol Notaris tersebut diserahkan oleh ahli waris kepada MPD atau Notaris lain, dengan tujuan apabila masyarakat membutuhkan salinan akta dari protokol Notaris yang meninggal dunia tersebut dapat diberikan, akan tetapi pada kenyataannya penyerahan Protokol Notaris tersebut tidak dilakukan sebagaimana yang telah ditentukan oleh undang-undang Jabatan Notaris dan peraturan perundang-undangan lainnya.

Maka dari itu penulis dengan ini menguraikan berdasarkan hal tersebut di atas bahwa protokol Notaris yang telah meninggal dunia wajib di serahkan kepada Notaris lain melalui ahli warisnya. Dalam hal penyerahan protokol Notaris tersebut oleh ahli warisnya tentu tidak lepas dari peranan dan tanggungjawab, mulai dari proses penunjukan protokol
Notaris oleh ahli waris yang di ajukan kepada MPD, sampai dengan penyerahan protokol Notaris kepada Notaris yang telah ditunjuk oleh MPD. Berdasarkan kenyataan seperti inilah dianggap perlu untuk ditelaah demi mendapatkan kesesuaian antara peraturan yang telah diberlakukan dengan praktek yang terjadi sebenarnya.

\section{METODE PENELITIAN}

Metode yang digunakan dalam penelitian ini adalah pendekatan yuridis empiris, yaitu suatu penelitian di samping melihat aspek hukum positif juga melihat seperti apa penerapan di lapangan dan masyarakat, data yang diteliti awalnya data sekunder untuk kemudian dilanjutkan dengan penelitian terhadap data primer di lapangan, yaitu penelitian terhadap para pihak-pihak yang terkait dalam hal-hal Praktek penyerahan protokol Notaris yang meninggal dunia.

Untuk meneliti suatu permasalahan mengenai hukum, maka pembahasan yang sangat relevan mengenai hukum tersebut adalah mengkajinya dengan menggunakan teori-teori tentang hukum, konsep-konsep hukum dan asas-asas hukum tersebut. Teori hukum tersebut dapat digunakan untuk menganalisa dan menerangkan suatu pengertian tentang hukum dan konsep yuridis dari hukum tersebut, yang relevan untuk menjawab semua permasalahan yang ada dan muncul dalam penelitian hukum. (Salim, HS, 2010: 54)

Dalam penulisan penelitian artikel ini, jenis pendekatan yang digunakan adalah pendekatan perundang-undangan 
Yofi Permana. R: Pengaturan Penyerahan Protokol Notaris Yang Telah Meninggal Dunia...

(statute approach), pendekatan konsep (conceptual approach) dan pendekatan perbandingan (comparative approach). Pendekatan perundang-undangan (statute approach) dilakukan untuk meneliti aturan-aturan hukum yang menjadi fokus penelitian, (Johnny Ibrahim, 2005: 302)

\section{HASIL DAN PEMBAHASAN}

\section{Penyerahan Protokol Notaris Yang Telah Meninggal Dunia Di Provinsi Sumatera Barat}

Protokol Notaris adalah kumpulan dokumen yang merupakan suatu arsip Negara yang harus disimpan dan dijaga keberadaannya, sebagaimana yang di atur dalam peraturan perundang-undangan. Berdasarkan pada Pasal 65 UUJN, terkait tanggung jawab Notaris terhadap protokol-protokolnya, Notaris berkewajiban serta bertanggungjawab secara penuh terhadap seluruh protokol yang dimilikinya, pertanggungjawaban tidak hanya sebatas telah usainya masa jabatan seorang Notaris melainkan tanggung jawabnya melekat seumur hidup Notaris tersebut. (Putra Topan Adiya, 2014).

Subekti mengemukakan pendapatnya menenai pengertian penyerahan, Penyerahan yang sering juga disebut dengan istilah "Levering" atau "overdracht" yang mempunyai dua arti, yang pertama perbuatan yang berupa penyerahan kekuasaan belaka ("feitelijke levering"), kedua perbuatan hukum yang bertujuan memindahkan hak milik kepada orang lain (juridische levering). (R. Subekti, 1980: 71)
Pendapat Subekti tersebut relevansi dengan Praktek Penyerahan Protokol Notaris yang telah meninggal dunia, yang mana merupakan suatu perbuatan hukum untuk dapat memindahkan kepemilikan dan tanggung jawab terkait dengan protocol- protokol Notaris yang meninggal dunia kepada Notaris penerima Protokol Notaris. Dengan telah diserahkannya protokol Notaris tersebut kepada Notaris penerima protokol maka Notaris penerima protokol mempunyai tanggung jawab untuk menjaga dan menyimpan protokol tersebut dan mempunyai kewenangan terhadap protokol sesuai dengan ketentuan yang telah diberikan oleh Undang-undang. (Cut Era Fitriyeni, Desember 2012: 391-404).

Pada prinsipnya, setiap kali ada Notaris yang meninggal dunia maka seluruh arsip atau protokolnya harus dipindahkan kepada Notaris lain selaku Notaris penerima Protokol oleh ahli waris dari Notaris yang telah meninggal dunia tersebut, sebagaimana penjelasan pada Pasal 35 Undang-undang Jabatan Notaris Perubahan atas Undang-Undang No. 30 Tahun 2004 tentang Jabatan Notaris (UUJN), Apabila Notaris meninggal dunia, suami/istri atau keluarga sedarah dalam garis lurus keturunan semenda sampai derajat kedua warisnya wajib memberitahukan kepada MPD Notaris ditempat wilayah kerja Notaris yang meninggal tersebut, paling lambat 7 (tujuh) hari kerja.

Apabila Notaris meninggal dunia pada saat menjalankan cuti, maka tugas jabatan Notaris dijalankan oleh Notaris 
Pengganti sebagai Pejabat Sementara Notaris paling lama 30 (tiga puluh) hari terhitung sejak tanggal Notaris meninggal dunia. (Lentera Hukum, Tengku Erwinsyahbana, Melinda, 2018: 317) Dan Pejabat Sementara Notaris tersebut menyerahkan protokol Notaris dari Notaris yang meninggal dunia tersebut kepada MPD dengan jangka waktu paling lama 60 (enam puluh) hari terhitung sejak tanggal Notaris tersebut meninggal dunia. (Hukum Online, 2018:).

Dalam hal Notaris meninggal dunia tersebut, maka protokol Notaris tersebut akan diserahkan kepada Notaris lain selaku Notaris penerima Protokol Notaris (Pasal 62 huruf a UU Jabatan Notaris). Penyerahan protokol dalam hal Notaris meninggal dunia, dilakukan oleh ahli waris Notaris kepada Notaris lain yang ditunjuk oleh MPD Notaris (Pasal 63 ayat (2) UUJNP). Melalui pasal ini dapat kita lihat bahwa Notaris lain yang akan menerima protokol Notaris yang meninggal dunia adalah Notaris yang telah ditunjuk oleh MPD berdasarkan usulan dari ahli waris. Penyerahan protokol tersebut dilakukan paling lama 30 (tiga puluh) hari dengan pembuatan berita acara penyerahan protokol Notaris yang ditandatangani oleh yang menyerahkan dan yang menerima protokol Notaris (Pasal 63 ayat (1) UU Jabatan Notaris). (Brinda Anitha Wirastuti dan J. Andi Hartanto. 2017:13)

Menurut pendapat Alexander, S.H., M.Kn, dari Notaris yang telah meninggal dunia tersebut, terdapat dua perbedaan dalam hal proses penyerahan protokol
Notaris, yang akan dilalui oleh Ahli Waris Notaris atau karyawan Notaris, adapun perbedaannya yaitu:

1) Proses yang pertama, apabila seorang Notaris meninggal dunia maka ahli waris melakukan pengajuan Notaris penerima protokol kepada MPD, yang mana prosesnya meliputi:

a) Ahli Waris wajib memberitahukan secara manual maupun elektronik kepada MPD di wilayah jabatan Notaris yang meninggal dunia tersebut perihal meninggalnya Seorang Notaris, dalam jangka waktu paling lama 7 (tujuh) hari terhitung sejak Notaris meninggal dunia (Pasal 35 ayat (2)) UUJNP, sedangkan pada Pasal 39 PerMen Hukum dan HAM nomor 25 tahun 2014 menyebutkan 'Dalam hal Notaris meninggal dunia ahli waris wajib memberitahukan secara manual atau elektronik kepada MPD di Wilayah jabatan Notaris yang meninggal dunia tersebut dalam jangka waktu paling lama 30 (tiga puluh).

b) Dalam hal Notaris tidak memiliki ahli waris maka pemberitahuan secara manual atau elektronik kepada MPD dilakukan oleh karyawan Notaris yang meninggal dunia tersebut dalam jangka waktu paling lama 30 (tiga puluh) sebagai mana yang tertuang dalam Pasal 39 PerMen Hukum dan HAM nomor 25 tahun 2014 . 
Yofi Permana. R: Pengaturan Penyerahan Protokol Notaris Yang Telah Meninggal Dunia...

2) Proses yang kedua, dengan meninggalnya seorang Notaris maka ahli waris atau karyawan Notaris melakukan penunjukan terhadap Pejabat Sementara Notaris yang ditujukan kepada MPD dan diteruskan kepada Kementerian Hukum dan Hak Asasi Manusia Republik Indonesia. Berdasarkan kepada rekomendasi dari ahli waris atau karyawan Notaris maka MPD menunjuk Pejabat Sementara Notaris paling lama dalam jangka waktu 14 hari terhitung sejak tanggal pemberitahuan. Protokol yang tidak diserahkan oleh ahli waris atau karyawan Notaris kepada MPD Notaris, maka MPD tetap mengajukan Pejabat Sementara Notaris (Pjs.Notaris) kepada Kementerian Hukum dan Hak Asasi Manusia Republik Indonesia. Setelah adanya pengajuan Pejabat Sementara Notaris (Pjs.Notaris) oleh MPD maka Kementerian Hukum dan Hak Asasi Manusia menerbitkan Surat Keputusan tentang pengangkatan Pejabat Sementara Notaris (Pjs.Notaris) dalam jangka waktu paling lama 30 (tiga puluh) hari terhitung sejak pengajuan oleh MPD kepada Menteri. (Alexander,2018).

Untuk dapat diangkat sebagai Pejabat Sementara Notaris (Pjs.Notaris) harus memenuhi persyaratan sebagai berikut (Pasal 40 ayat (2) dan ayat (3) PerMen Hukum dan HAM nomor 25 tahun 2014 :

1) Warga Negara Indonesia (WNI);

2) Berijazah Sarjana Hukum; dan
3) Telah bekerja sebagai karyawan Kantor Notaris paling singkat 24 (dua puluh empat) bulan berturut-turut. Dengan disertai dokumen pendukung, seperti:

a. Fotokopi Ijazah sarjana hukum yang telah dilegalisasi;

b. Fotokopi Kartu Tanda Penduduk yang telah dilegalisasi;

c. Asli surat keterangan catatan kepolisian setempat;

d. Asli surat keterangan sehat jasmani dari dokter rumah sakit dan asli surat keterangan sehat rohani dari psikiater rumah sakit;

e. Pasfoto berwarna ukuran $3 \times 4$ $\mathrm{cm}$ sebanyak 4 (empat) lembar;

f. Daftar riwayat hidup; dan

g. Surat keterangan telah bekerja sebagai karyawan kantor Notaris paling singkat 24 (dua puluh empat) bulan berturut-turut.

Sebelum menjalankan jabatannya Pejabat Sementara Notaris (Pjs.Notaris) wajib mengucapkan sumpah/janji jabatan Notaris dengan lafal sesuai dengan ketentuan pada Pasal 8 ayat (4) PerMen Hukum dan HAM nomor 25 tahun 2014, di hadapan Menteri atau pejabat yang berwenang yang telah ditunjuk sesuai dengan ketentuan perundang-undangan. Dalam hal mengusulkan atau mengajukan Notaris lain sebagai penerima protokol Notaris, ahli waris atau karyawan Notaris dapat mengusulkan Notaris pemegang Protokol Notaris kepada MPD dan MPD meneruskan atau menyampaikan kepada Menteri secara manual atau 
elektronikdalam jangka waktu 14 (empat belas) hari terhitung sejak masa jabatan Pejabat sementara Notaris berakhir. Penyampaian penunjukan Notaris lain sebagai pemegang protokol oleh Majelis Pengawas Daerah dengan melampirkan syarat-syarat sebagai berikut:

1. Surat Permohonan;

2. Fotokopi Keputusan pengangkatan sebagai Notaris pengganti yang telah dilegalisasi;

3. Fotokopi Kutipan Akta kematian/Surat Keterangan Kematian yang telah dilegalisir;

4. Asli surat penunjukan Notaris lain sebagai Pemegang protokol Notaris; dan

5. Fotokopi Surat keterangan ahli waris dari pejabat yang berwenang dan telah dilegalisir (dalam hal Notaris yang meninggal dunia mempunyai ahli waris).

Menurut Pendapat Iwan Maulana, S.H., M.Kn, Sebelum melakukan serah terima atau penyerahan protokol Notaris, maka harus memastikan bahwa semua protokol Notaris sudah lengkap, Notaris penerima protokol Notaris juga harus menghitung serta memeriksa berapa jumlah akta beserta data-data atau warkahnya dan mencocokkannya sebagaimana yang tertera dalam Berita Acara Serah terima Protokol Notaris. Dalam hal penyerahan protokol Notaris yang meninggal dunia tersebut dapat dilakukan oleh ahli waris, Pejabat sementara Notaris dan Notaris pengganti untuk menyelesaikan semua protokol Notaris tersebut. Penyerahan protokol
Notaris tersebut sebagaimana yang dimaksud dalam Pasal 62 UUJN-P dilaksanakan paling lama 60 (enam puluh) hari, terhitung sejak Notaris Pembuat akta meninggal dunia dengan pembuatan berita acara penyerahan protokol Notaris yang ditandatangani oleh Notaris penerima protokol Notaris, serta pihak yang menyerahkan dan Ketua MPD Notaris. (Iwan Maulana, 2018)

Berkaitan dengan Praktek penyerahan Protokol Notaris yang meninggal dunia tersebut, maka protokol Notaris berdasarkan hasil wawancara dengan Nyonya Resty Handayani. S.H., M.Kn (Notaris/PPAT di Kota Pariaman selaku penerima protokol Notaris dari Almarhumah Ibu Rita Yusneli, S.H) menyatakan bahwa praktek penyerahan protokol Notaris yang meninggal dunia telah sesuai dengan ketentuan pada Pasal 63 ayat (2) UUJN, dimana penunjukan sebagai penerima Protokol Notaris yang dilakukan oleh MPD pada saat itu, setelah penunjukan dilakukan oleh MPD, Notaris penerima Protokol mengurus segala sesuatunya kepada Kanwil Kementerian Hukum dan Hak Asasi Manusia Sumatera Barat, untuk menentukan jadwal untuk serah terima Protokol Notaris yang dilakukan pada Kantor Wilayah Kementerian Hukum dan Hak Asasi Manusia Sumatera Barat, setelah dilakukan serah terima protokol Notaris dan penandatanganan Berita Acara Serah terima Protokol Notaris yang dilakukan pada tahun 2016. (Resty Handayani, 2018). 
Yofi Permana. R: Pengaturan Penyerahan Protokol Notaris Yang Telah Meninggal Dunia...

Notaris Penerima Protokol Notaris mempunyai peranan yang sangat penting dalam kehidupan masyarakat, menurut pendapat Ja'afar, $\mathrm{SH}$, salah satu Notaris/PPAT senior di Kota Padang sebagaimana yang tertuang dalam Pasal 16 ayat (1) huruf b dalam UUJN yaitu mewajibkan setiap Notaris untuk menyimpan minuta akta sebagai bagian dari protokol Notaris dan mewajibkan setiap Notaris untuk mengeluarkan Grose Akta, Salinan Akta, atau Kutipan Akta berdasarkan minuta Akta atas permintaan para pihak. (Ja'afar, 2018)

Setiap Notaris penerima protokol Notaris haruslah berhati-hati dalam bertindak terutama dalam hal penyimpanan setiap protokol Notaris yang diserahkan kepadanya. Setiap calon Notaris pada saat mendaftarkan diri sebagai Notaris kepada Kementerian Hukum dan Hak Asasi Manusia harus membuat dan menandatangani Surat Pernyataan yang mana isinya "Bersedia menerima Protokol Notaris dari Notaris lain", jadi tidak ada alasan lain bagi seorang Notaris untuk menolak sebagai penerima Protokol Notaris yang telah ditunjuk oleh MPD untuk menerima dan memelihara serta menjaga protokol Notaris tersebut. (Jurnal Akta, Roeri Andriana, Munsyarif Abdul Chalim. 2017: 226).

Menurut Pasal 1 angka 2 UUJN yang dimaksud dengan Pejabat Sementara Notaris adalah seorang yang sementara menjabat sebagai notaris untuk menjalankan jabatan notaris yang meninggal dunia, diberhentikan atau diberhentikan sementara. Notaris dalam menjalankan tugas jabatannya diberikan wewenang tertentu. Notaris yang meninggal dunia berarti sudah tidak dapat menjalankan kewenangan apapun, sehingga dengan demikian tidak dapat jabatan notaris yang disandangnya digantikan oleh orang lain.

\section{Pertanggungjawaban Ahli Waris Terhadap Protokol Notaris Yang Telah Meninggal Dunia Di Provinsi Sumatera Barat}

Notaris berkewajiban secara langsung terhadap protokol Notaris. Namun pada kenyataannya yang terjadi di masyarakat saat ini, tidak seluruhnya Notaris tersebut memahami prosedur penyerahan protokol Notaris dan melaksanakan kewajibannya untuk menyerahkan protokol Notaris kepada Notaris yang telah ditunjuk oleh Majelis Pengawas Daerah. Sama halnya apabila ada Notaris yang meninggal dunia, ahli waris dari Notaris yang bersangkutan kadang tidak memahami tata cara atau prosedur peralihan protokol Notaris. Hal ini disebabkan karena minimnya sosialisasi mengenai protokol Notaris, baik itu dari Notaris itu sendiri kepada keluarganya, Notaris kepada para karyawan, dari MPD dan organisasi Notaris kepada para Notaris maupun dari MPD dan organisasi Notaris kepada masyarakat luas.

Minimnya sosialisasi mengenai protokol Notaris ini menyebabkan kesimpangsiuran masyarakat yang membutuhkan protokol yang seharusnya bisa disimpan dan diserahkan kepada Notaris yang telah ditunjuk oleh Majelis 
Pengawas Daerah. Secara tidak langsung dapat berakibat fatal bahkan dapat menimbulkan kerugian material yang sangat besar terhadap masyarakat yang akan atau masih membutuhkan akta yang terdapat di dalam protokol Notaris yang purna tugas atau yang telah meninggal dunia tersebut untuk keperluan dan memperoleh kepastian hukumnya.

Meninggalnya seorang Notaris, selain meninggalkan masalah-masalah mengenai pekerjaan yang tertunda tentunya juga akan meninggalkan permasalahan lainnya terkait dengan protokol Notaris. Di dalam UUJN dan UUJNP Pasal 1 butir 13 disebutkan bahwa yang dimaksud dengan protokol Notaris adalah kumpulan dokumen yang merupakan arsip negara yang harus disimpan dan dipelihara oleh Notaris sesuai dengan ketentuan peraturan perundang-undangan. Penyimpanan dan pemeliharaan Protokol Notaris tersebut terus berlangsung walaupun Notaris yang bersangkutan telah pensiun atau bahkan sudah meninggal dunia. Protokol Notaris tersebut diserahkan kepada Notaris lain sebagai Pemegang Protokol Notaris.

Pada Pasal 35 ayat (2) UndangUndang No. 2 Tahun 2014 tentang Jabatan Notaris, secara tegas menjelaskan bahwa Ahli waris dan/atau keluarga dari Notaris yang telah meninggal dunia wajib memberitahukan kepada Majelis Pengawas Daerah (MPD) Notaris paling lambat 7 (Tujuh) hari kerja. Sebagaimana ketentuan dalam Pasal 62 huruf a UUJN menjelaskan bahwa dalam hal Notaris meninggal dunia, maka protokol Notaris tersebut diserahkan kepada Notaris lain.
Penyerahan protokol Notaris yang meninggal dunia akan dilakukan oleh ahli waris kepada Notaris lain yang ditunjuk oleh MPD sebagaimana tertuang dalam Pasal 63 ayat (2) UUJN.

Kewajiban ahli waris notaris meninggal dunia selain memberitahukan kepada Majelis Pengawas Daerah, juga wajib untuk menyerahkan protokol notaris kepada Notaris penerima protokol Notaris. Protokol notaris harus diserahkan paling lama 30 (tiga puluh) hari dengan pembuatan berita acara penyerahan protokol notaris yang ditandatangani oleh yang menyerahkan dan yang menerima protokol notaris. protokol Notaris tersebut terdiri atas:

1) Bundel minuta akta;

2) Buku daftar akta protes;

3) Buku daftar wasiat;

4) Buku daftar akta atau repertorium;

5) Buku daftar surat dibawah tangan yang disahkan;

6) Buku daftar surat dibawah tangan yang dibukukan;

7) Klapper untuk daftar akta, dan;

8) Klaper untuk daftar surat dibawah tangan yang disahkan; serta

9) Buku-buku lain yang harus dibuat, diisi dan disimpan oleh Notaris yang diwajibkan oleh peraturan perundang-undangan yang berlaku.

Selanjutnya apabila ahli waris tidak menyerahkan protokol notaris dalam jangka waktu 30 (tiga puluh) hari sebagaimana dimaksud pada Pasal 63 ayat (1) UUJN, maka tindakan yang harus dilakukan oleh Majelis Pengawas Daerah adalah mengambil protokol Notaris 
Yofi Permana. R: Pengaturan Penyerahan Protokol Notaris Yang Telah Meninggal Dunia...

tersebut karena hal itu adalah kewenangan Majelis Pengawas Daerah, sebagaimana ketentuan Pasal 63 ayat (6) UUJN. (Jurnal Ilmiah Brinda Anitha Wirastuti dan J. Andi Hartanto, 2017: 282)

Didalam prakteknya masih ada Ahli waris Notaris yang belum atau terlambat menyerahkan protokol Notaris tersebut kepada Notaris penerima protokol Notaris. Hal ini dapat menimbulkan kesimpangsiuran bagi masyarakat yang membutuhkan keterangan atau membutuhkan salinan dari minuta akta yang telah dibuatnya, bahkan dapat menimbulkan kerugian. Dalam hal ini ahli waris memiliki peranan dan tanggungjawab tetapi tidak ada konsekwensi ataupun sanksi yang dapat diberikan kepada ahli waris Notaris apabila terjadi keterlambatan dan ataupun kelalaian dalam penyerahan Protokol Notaris, karena sifat dalam menjalankan jabatannya seorang Notaris wajib menjunjung tinggi kode etik seorang Notaris yaitu menjaga kerahasiaan akta yang dibuatnya kepada siapapun juga termasuk istri, keluarga, maupun pihak lain yang tidak terkait dalam akta yang dibuatnya tersebut. Dengan tidak adanya sanksi bagi ahli waris yang terlambat menyerahkan Protokol Notaris dengan sengaja melalaikan atau tidak menyerahkan, maka sangat diperlukan sikap yang proaktif bagi Majelis Pengawas Daerah (MPD) Notaris, karena Dalam UUJN dan UUJNP Tidak adanya aturan yang mengatur tentang sanksi yang ditujukan kepada ahli waris Notaris apabila tidak segera menyerahkan protokol Notaris kepada Notaris penerima protokol.

\section{Tindakan Hukum Yang Dilakukan Oleh Majelis Pengawas Daerah (MPD) Terhadap Protokol Notaris Yang Meninggal Dunia Di Provinsi Sumatera Barat}

Setiap Notaris dalam menjalankan jabatannya senantiasa diawasi oleh lembaga yang diberikan kewenangan oleh Menteri. Dengan berlakunya UUJN, mengenai pengawasan, pembinaan, pemeriksaan, dan penjatuhan sanksi Notaris, tugas tersebut dilakukan oleh Menteri Hukum dan HAM dengan membentuk Majelis Pengawas Notaris. Dengan tujuan untuk menjaga dan melindungi kepentingan masyarakat terhadap akta Notaris sebagai akta otentik yang merupakan bagian dari protokol Notaris, berkaitan dengan peranannya sebagai alat bukti tertulis yang terkuat dan terpenuh.

Majelis Pengawas Notaris sebagai satu-satunya instansi yang berwenang melakukan pengawasan, pembinaan, pemeriksaan dan menjatuhkan sanksi terhadap Notaris, secara umum pengawasan dalam hal ini merupakan suatu kegiatan yang dilakukan oleh lembaga atau badan pengawas dalam melihat, memperhatikan, mengamati, mengontrol, menilik, dan menjaga serta memberikan pengarahan terhadap Notaris. (Ria Trisnomurti, I Gusti Bagus Suryawan, 2017:127-140)

Fungsi Majelis Pengawas seperti yang dimaksud untuk melaksanakan pembinaan dan pengawasan terhadap 
Notaris. Dalam kaitan ini, menghimbau kepada para Notaris agar berhati-hati dalam menjalankan tugas jabatannya, agar bekerja sesuai peraturan yang berlaku, serta bersikap netral tidak memihak. Demi menjaga keluhuran dan martabat jabatan seorang Notaris.

Majelis pengawas dalam UUJN dan UUJN Perubahan diatur dalam pasal-pasal sebagai berikut :

Menurut ketentuan umum Pasal 1 ayat (6) UUJN Perubahan:

"Majelis Pengawas adalah suatu badan yang mempunyai kewenangan dan kewajiban untuk melaksanakan pembinaan dan pengawasan terhadap Notaris".

Kewenangan MPD berdasarkan ketentuan Pada Pasal 70 UUJN adalah:

a. Menyelenggarakan sidang untuk memeriksa adanya dugaan pelanggaran Kode Etik Notaris atau pelanggaran pelaksanaan Jabatan Notaris;

b. Melakukan pemeriksaan terhadap protokol Notaris secara berkala 1 (satu) kali dalam 1 (satu) tahun atau setiap waktu yang dianggap perlu;

c. Memberikan izin cuti untuk waktu sampai dengan 6 (enam) bulan;

d. Menetapkan Notaris Pengganti dengan memperhatikan usul Notaris yang bersangkutan;

e. Menentukan tempat penyimpanan Protokol Notaris yang pada saat serah terima Protokol Notaris telah berumur 25 (dua puluh lima) tahun atau lebih;

f. Menunjuk Notaris yang akan bertindak sebagai pemegang sementara Protokol Notaris yang diangkat sebagai Pejabat Negara sebagaimana dimaksud dalam Pasal 11 ayat (4);

g. Menerima laporan dari masyarakat mengenai adanya dugaan pelanggaran Kode Etik Notaris atau pelanggaran ketentuan dalam Undang-undang ini; dan

h. Membuat dan menyampaikan laporan sebagaimana dimaksud pada huruf $a$, huruf $b$, huruf $c$, huruf $\mathrm{d}$, huruf e, huruf $\mathrm{f}$ dan huruf g kepada Majelis Pengawas Wilayah.

Mengenai tempat dan jangka waktu penyimpanan Protokol Notaris pada pasal 70 UUJN huruf e, sudah sepantasnya diperlukan penyimpanan dalam bentuk elektronik, pengalihan Protokol Notaris dalam bentuk elektronik penting untuk diimplementasikan karena Notaris dalam menjalankan kewajibannya untuk

menyimpan dokumen-dokumen tersebut menjadi aman, efektif, dan efisien dibandingkan dengan dokumen dalam bentuk kertas/surat yang rentan terhadap kerusakan dan mudah hilang. (Jurnal Repertorium, Mohamat Riza Kuswanto, 2017;64).

Kewajiban dari MPD sebagai mana yang terdapat dalam Pasal 71 UUJN, yaitu:

a. Mencatat pada buku daftar yang termasuk dalam protokol Notaris dengan menyebutkan tanggal pemeriksaan, jumlah akta serta jumlah surat di bawah tangan yang disahkan dan yang dibukukan sejak tanggal pemeriksaan terakhir;

b. Membuat berita acara pemeriksaan dan menyampaikannya kepada MPW 
Yofi Permana. R: Pengaturan Penyerahan Protokol Notaris Yang Telah Meninggal Dunia...

setempat, dengan tembusan kepada Notaris yang bersangkutan, organisasi Notaris, dan MPP;

c. Merahasiakan isi akta dan hasil pemeriksaan;

d. Menerima salinan yang telah disahkan dari daftar akta dan daftar lain dari Notaris dan merahasiakannya;

e. Memeriksa laporan masyarakat terhadap Notaris dan menyampaikan hasil pemeriksaan tersebut kepada MPW dalam waktu 30 hari, dengan tembusan kepada pihak yang melaporkan, Notaris yang bersangkutan, MPP dan organisasi Notaris;

f. Menyampaikan permohonan banding terhadap keputusan penolakan cuti.

Selain itu kewenangan dari MPD juga diatur dalam Peraturan Menteri Hukum dan Hak Asasi Manusia Republik Indonesia nomor: M.02.PR08.10 Tahun 2004, tentang Tata Cara Pengangkatan Anggota, Pemberhentian Anggota, Susunan Organisasi, Tata Kerja dan Tata Cara Pemeriksaan Majelis Pengawas Notaris, dan juga diatur dengan Keputusan Menteri Hukum dan Hak Asasi Manusia Republik Indonesia nomor: M.39-PW.07.10 Tahun 2004 tentang Pedoman Pelaksanaan Tugas Majelis Pengawas Notaris.

Pengawasan terhadap pelaksanaan jabatan Notaris di tingkatan yang paling tinggi dilakukan oleh Majelis Pengawas Pusat, yang berkedudukan di ibukota negara, yang memiliki kewenangan untuk: (Jurnal Ilmiah Brinda Anitha Wirastuti dan J. Andi Hartanto, 2017:278).
1) Menyelenggarakan sidang untuk memeriksa dan mengambil keputusan dalam tingkat banding terhadap penjatuhan sanksi dan penolakan cuti;

2) Memanggil Notaris terlapor untuk dilakukan pemeriksaan;

3) Menjatuhkan sanksi pemberhentian sementara; dan

4) Mengusulkan pemberhentian sanksi berupa pemberhentian dengan tidak hormat kepada Menteri.

Berdasarkan pada ketentuan Pasal 63 ayat (6) UUJNP yang menegaskan bahwa: "Dalam hal Protokol Notaris tidak diserahkan dalam jangka waktu 30 (tiga puluh) hari sebagaimana dimaksud pada ayat (1), Majelis Pengawas Daerah berwenang untuk mengambil Protokol Notaris", apabila ada Notaris yang meninggal dunia dan protokol-protokol Notarisnya belum diserahkan oleh para ahli waris Notaris kepada MPD atau bahkan belum ada Notaris pemegang protokol maka seharusnya MPD segera bertindak proaktif dan segera mengambil langkah untuk menyelesaikan protokol Notaris yang telantar. Undang - undang telah memberikan kewenangan sepenuhnya kepada MPD untuk menyelesaikan permasalahan protokol Notaris yang belum terselesaikan. Di sinilah diperlukan ketegasan MPD mengenai proses penyerahan dan penyimpanan protokol-protokol Notaris yang telah meninggal dunia tersebut agar sesuai dengan peraturan. (Alexander, 2018).

Berdasarkan uraian tersebut diatas, UUJN telah memberikan kewenangan 
kepada majelis pengawas Notaris, masyarakat dan organisasi Notaris, untuk melakukan pengawasan melalui mekanisme dan tata cara sebagaimana telah diuraikan di atas, terhadap akta Notaris dan Notaris dalam pelaksanaan jabatannya sebagai pemegang protokol Notaris.

\section{SIMPULAN}

1. Berdasarkan ketentuan dalam pasal 63 UUJN dan UUNJ-P dijelaskan bahwa penyerahan protokol Notaris dilakukan paling lama 30 (tiga puluh) hari dengan pembuatan berita acara penyerahan protokol Notaris yang ditandatangani oleh yang menyerahkan (ahli waris) dan yang menerima Protokol Notaris (Notaris penerima Protokol Notaris). Dalam hal ini ahli waris Notaris bertanggungjawab tidak hanya sebatas pemberitahuan kepada MPD tetap juga bertanggungjawab dalam hal pemberkasan protokol Notaris tersebut selama jangka waktu 30 (tiga puluh) hari setelah Notaris meninggal dunia. Kewenangan MPD dalam hal ini tidak saja sebatas dalam hal pengawasan dan pembinaan, serta menunjuk Notaris penerima Protokol Notaris tetapi juga memberi kepastian tentang keberadaan dan kepada siapa protokol Notaris tersebut diserahkan sampai dengan batasan waktu yang telah ditetapkan oleh UUJN dan UUJN-P.

2. Dalam UUJN dan UUJNP hanya mengatur tentang prosedur peralihan protokol Notaris saja, tetapi tidak ada mencakup sanksi baik kepada ahli waris ataupun Pejabat sementara Notaris yang lalai dalam hal penyerahan Protokol Notaris yang telah meninggal dunia tersebut. Hal ini disebabkan karena Kurangnya sosialisasi dari Pihak MPD dan Organisasi Ikatan Notaris (INI) kepada Notaris yang masih aktif serta anggota keluarga dari Notaris, sehingga ahli waris tidak memahami dan tidak memiliki pengetahuan dan pemahaman tentang pentingnya Protokol Notaris tersebut. dengan kekurangan pemahaman atas protokol tersebut mengakibatkan Protokol Notaris tersebut telantar atau terlambatnya diserahkan kepada Notaris lain. sehingga hak-hak klien terkait dengan alat bukti akan sulit atau bahkan tidak bisa terpenuhi.

\section{DAFTAR PUSTAKA}

\section{Buku}

Bambang Waluyo, 2008, Penelitian Hukum Dalam Praktek, Sinar Grafika, Jakarta.

Habib Adjie (I), 2008, Sanksi Perdata dan Administif Terhadap Notaris Sebagai Pejabat Publik, PT.Refika Aditama, Bandung.

, 2009, Hukum Notaris Di Indonesia, PT.Refika Aditama, Bandung.

R.Subekti 1980, Pokok-pokok Hukum Perdata, PT.Intermasa, Jakarta.

Sjaifurrachman, 2011, Aspek

Pertanggungjawaban Notaris

Dalam Pembuatan Akta, CV. Mandar Maju, Surabaya. 
Yofi Permana. R: Pengaturan Penyerahan Protokol Notaris Yang Telah Meninggal Dunia...

\section{Jurnal Ilmiah}

Cut Era Fitriyeni, Tanggung Jawab Notaris Terhadap Penyimpanan Minuta Akta sebagai Bagian dari Protokol Notaris, Kanun Jurnal Ilmu Hukum 50.58.Th.XIV (Desember 2012).

Jurnal Ilmiah, Brinda Anitha Wirastutidan J. Andi Hartanto Akibat Hukum Protokol

Notsris yang tidak diserahkan oleh Ahli waris kepada Notaris lain, AlQanun, Vol.20, No.2, Desember 2017.

Jurnal Notariil, Ria Trisno Murti, I Gusti Bagus Suryawan, Tugas dan Fungsi Majelis Pengawas Daerah dalam Menyelenggarakan

Pengawasan, Pemeriksaan, dan Penjatuhan Sangksi Terhadap Notaris, Vol.2, No.2, November 2017.

Tengku Erwinsyahbana,

Melinda, Kewenangan dan Tanggung Jawab Notaris Pengganti setelah Pelaksana Tugas dan Jabatan Berakhir, Lentera Hukum, Volume 5 Issue 2 (2018).pp.305321.

Mohamat Riza Kuswanto, Urgensi Penyimpanan Protokol Notaris dalam bentuk Elektronikl dan Kepastian Hukumnya di Indonesia, Jurnal Repertorium, Volume IV.No.2, Juli-Desember 2017.

Putra Topan Adiya, Tinjauan Yuridis terhadap pelaksanaan Jabatan Notaris atas Minuta Akta yang Rusak, Jurnal.2014.
Roeri Andriana, Munsyarif Abdul Chalim, Akibat Hukum Bagi Notaris Yang Meniolak Protokol Dari Notaris Lain, Jurnal Akta, Vol.4 No.2, Juni 2017.

\section{Undang-Undang}

Undang-Undang Dasar 1945.

Kitan Undang-Undang Hukum Perdata (KUH Perdata).

Undang-Undang Republik Indonesia Nomor 30 Tahun 2004 Tentang Jabatan Notaris. Undang-Undang Republik Indonesia Nomor 2 Tahun 2014 Tentang Perubahan Atas Undang-Undang Nomor 30 Tahun 2004Tentang Jabatan Notaris.

Peraturan Menteri Hukum Dan HAM Republik Indonesia Nomor : M.02.PR.08.10 Tahun 2004

Tentang Tata Cara Pengangkatan Anggota, Pemberhentian Anggota, Susunan Organisasi, Tata Kerja, Dan Tata Cara Pemeriksaan Majelis Pengawas Notaris.

Keputusan Menteri Hukum Dan HAM Republik Indonesia Nomo : M.39-PW.07.10 Tahun 2004 Tentang Pedoman Pelaksanaan Tugas Majelis Pengawas Notaris.

Peraturan Menteri Hukum dan HAM nomor M.03.HT.03.10.Tahun 2007 tentang Pengambilan Minuta Akta dan Pemanggilan Notaris,

Peraturan Menteri Hukum dan HAM Republik Indonesia nomor: M.HH06.AH.02.10. Tahun 2009 tentang Sekretariat Majelis Pengawas Notaris.

Peraturan Meneri Hukum dan HAM Republik Indonesia, nomor 25 tahun 
Jurnal Cendekia Hukum: Vol. 5, No 1, September 2019

2014 Tentang Tata cara Pengangkatan, perpindahan, pemberhentian, dan Perpanjangan Masa Jabatan Notaris.

\section{Internet}

http://www.hukumonline.com/klinik/detai 1/1t5 1665a7f58572/prosedur- penyerahan-prot okol-notaris-yangmeninggal-dunia, hari selasa tanggal 07 Agustus 2018, jam 15.30WIB.

http://www.m.hukumonline.com/klinik/de tail/ golongan-ahli-waris-menurutKUHPerd ata, hari jumat tanggal 26 Oktober 2018, jam 14.00WIB. 